\title{
Cholecystokinin System Is Involved in the Anorexigenic Effect of Peripherally Applied Palmitoylated Prolactin-Releasing Peptide in Fasted Mice
}

\author{
Zdenko PIRNÍK ${ }^{1,2,3}$, Lucia KOŘÍNKOVÁ ${ }^{2,5}$, Jana OSACKÁ3 ${ }^{3}$, Blanka ŽELEZNÁ2 \\ Jaroslav KUNES ${ }^{2,4}$, Lenka MALETÍNSKÁ ${ }^{2}$ \\ ${ }^{1}$ Institute of Physiology, Faculty of Medicine, Comenius University in Bratislava, Bratislava, \\ Slovak Republic, ${ }^{2}$ Institute of Organic Chemistry and Biochemistry of the Czech Academy of \\ Sciences, Prague, Czech Republic, ${ }^{3}$ Biomedical Research Center, Slovak Academy of Sciences, \\ Institute of Experimental Endocrinology, Bratislava, Slovak Republic, ${ }^{4}$ Institute of Physiology of \\ the Czech Academy of Sciences, Prague, Czech Republic, ${ }^{5}$ First Faculty of Medicine, Charles \\ University, Prague, Czech Republic
}

Received April 1, 2021

Accepted April 22, 2021

Epub Ahead of Print June 2, 2021

\section{Summary}

Prolactin-releasing peptide (PrRP) has been proposed to mediate the central satiating effects of cholecystokinin (CCK) through the vagal CCK1 receptor. PrRP acts as an endogenous ligand of G protein-coupled receptor 10 (GPR10), which is expressed at the highest levels in brain areas related to food intake regulation, e.g., the paraventricular hypothalamic nucleus (PVN) and nucleus of the solitary tract (NTS). The NTS and PVN are also significantly activated after peripheral CCK administration. The aim of this study was to determine whether the endogenous PrRP neuronal system in the brain is involved in the central anorexigenic effect of the peripherally administered CCK agonist JMV236 or the CCK1 antagonist devazepide and whether the CCK system is involved in the central anorexigenic effect of the peripherally applied lipidized PrRP analog palm-PrRP31 in fasted lean mice. The effect of devazepide and JMV236 on the anorexigenic effects of palmPrRP31 as well as devazepide combined with JMV236 and palmPrRP31 on food intake and Fos cell activation in the PVN and caudal NTS was examined. Our results suggest that the anorexigenic effect of JMV236 is accompanied by activation of PrRP neurons of the NTS in a CCK1 receptor-dependent manner. Moreover, while the anorexigenic effect of palm-PrRP31 was not affected by JMV236, it was partially attenuated by devazepide in fasted mice. The present findings indicate that the exogenously influenced CCK system may be involved in the central anorexigenic effect of peripherally applied palm-PrRP31, which possibly indicates some interaction between the CCK and PrRP neuronal systems.

\section{Key words}

Lipidized prolactin-releasing peptide analog - Cholecystokinin system - Cholecystokinin 1 receptor - Hypothalamic paraventricular nucleus $\bullet$ Nucleus of the solitary tract $\bullet$ c-Fos

\section{Corresponding author}

Lenka Maletínská, Institute of Organic Chemistry and Biochemistry of the Czech Academy of Sciences, 16610 Prague, Czech Republic. E-mail: maletin@uochb.cas.cz

\section{Introduction}

Anorexigenic neuropeptide prolactin-releasing peptide (PrRP), which has a structural RF-amide motif at the $\mathrm{C}$-terminus that is important for its biological activity, is an endogenous ligand of $\mathrm{G}$ protein-coupled receptor 10 (GPR10), although it also has high binding affinity for neuropeptide FF receptor type 2 (NPFF-2R) (Kuneš et al. 2016, Pražienková et al. 2019). PrRP is mainly expressed in the nucleus of the solitary tract (NTS) of the brainstem, ventrolateral medulla and dorsomedial hypothalamic nucleus (DMN), and PrRP-positive fibers are found in the hypothalamus, amygdala and area postrema (AP), which are all areas connected with food intake regulation, as previously reviewed (Dodd and Luckman 2013, Pražienková et al. 2019, Quillet et al. 2016). The highest expression of GPR10 mRNA in rats was detected in the

PHYSIOLOGICAL RESEARCH • ISSN 1802-9973 (online) - an open access article under the CC BY-NC-ND 4.0 license (c) 2021 Institute of Physiology of the Czech Academy of Sciences, Prague, Czech Republic Fax +420 241062 164, e-mail: physres@fgu.cas.cz,www.biomed.cas.cz/physiolres 
reticular nucleus of the thalamus, paraventricular hypothalamic nucleus (PVN), periventricular hypothalamic nucleus, DMN, AP and NTS. A moderate level of GPR10 expression was also found in the anterior pituitary and ventromedial nuclei (Ibata et al. 2000, Roland et al. 1999).

Initial studies showed that intracerebroventricular (i.c.v.) administration of PrRP reduced food intake and increased energy expenditure in rodents (Lawrence et al. 2000, Lawrence et al. 2002). Moreover, Ellacott et al. (2002) suggested that the anorexigenic action of PrRP is regulated by the adiposity signal leptin. Moreover, i.c.v. co-administration of PrRP and leptin to rats lowered food intake by an additive effect and increased body temperature more than either peptide alone. PrRP was also proposed to mediate some of the central satiating actions of the peptide hormone cholecystokinin (CCK) released from the gastrointestinal tract (GIT) (Lawrence et al. 2002). CCK is released from the GIT following the consumption of a meal and exerts its short-term anorexigenic effect via CCK1 receptors located on vagal afferents. Vagal efferents synapse to second-order neurons in the NTS by releasing neurotransmitters and neuropeptides (Luckman 1992, Peters et al. 2006). In such a route, the intraperitoneal (i.p.) injection of CCK activated c-Fos expression as a marker of neuronal activation in NTS neurons producing PrRP (Lawrence et al. 2002). CCK-induced hypothalamic c-Fos activation is strongly associated with the activation of noradrenergic A2 neurons within the NTS that express c-Fos even after peripheral injection of low doses of CCK (Maniscalco and Rinaman 2013, Wall et al. 2020). In fasted or satiated GPR10 KO mice, i.c.v. administration of PrRP did not reduce food intake compared to their wild-type controls. The administration of CCK did not result in the inhibition of food intake in GPR10 KO mice, suggesting that PrRP is involved in the central satiating actions of CCK (Bechtold and Luckman 2006). In addition, Cre recombinase-mediated reactivation of PrRP in the brainstem rescued the anorectic action of CCK (Dodd et al. 2014). On the other hand, endogenous CCK is physiologically involved in feeding control during fasting via the hypothalamic PVN (Cano et al. 2003), where CCK1 receptors are abundant (Woodruff et al. 1991). In addition, the activation of CCK neurons of the NTS that innervate the PVN stimulates appetite (D'Agostino et al. 2016, Roman et al. 2017).

PrRP acts centrally; therefore, the potential of
PrRP to decrease food intake after peripheral administration depends on its ability to reach receptors in the brain and thus facilitate its central effect. Our group designed analogs of PrRP lipidized at the N-terminus, myristoylated PrRP20 (myr-PrRP20) and palmitoylated PrRP31 (palm-PrRP31), and PrRP31 palmitoylated at position 11 were shown to significantly lower food intake in fasted lean mice after subcutaneous (s.c.) administration and to lower body weight and improve metabolic parameters in diet-induced obese mice (Maletínská et al. 2015, Pražienková et al. 2017). Moreover, only palm-PrRP31 and myr-PrRP20, but not natural PrRP20, PrRP31 or octanoylated PrRP31, showed longer stability in rat plasma and after s.c. administration significantly increased c-Fos immunoreactivity in hypothalamic and brainstem nuclei involved in food intake regulation, such as the PVN, arcuate hypothalamic nucleus (Arc) and NTS (Maletínská et al. 2015). Finally, palm-PrRP31 administration resulted in significantly increased c-Fos levels in lateral hypothalamic area (LHA) hypocretin neurons and PVN oxytocin neurons (Pirnik et al. 2015).

Although PrRP mediates some of the central satiating actions of CCK and endogenous CCK is physiologically involved in feeding control during fasting via the hypothalamic PVN, there is no information to date regarding whether the CCK system may also be involved in the central anorexigenic effect observed after peripherally administered lipidized PrRP analog. Therefore, the anorexigenic activity of palm-PrRP31 with neuronal activity of the NTS and PVN, brain structures involved in homeostatic food control, was studied in overnight-fasted mice in which the "silent" CCK system, i.e., minimal endogenous peripheral CCK activity caused by fasting, was pharmacologically influenced by devazepide (Dev), a CCK1 receptor antagonist, and JMV236, a stable anorexigenic CCK analog (Maletínská et al. 1992).

\section{Methods}

\section{Applied drugs}

The cholecystokinin analog JMV236 (Asp-Tyr (SO3H)-Nle-Gly-Trp-Nle-Asp-Phe-NH2, PolyPeptide, Strasbourg, France), CCK-1 receptor antagonist Dev (L364,718) (gift from ML Laboratories, Liverpool, UK) and human palmitoylated PrRP analog palm-PrRP31 (Npalm-SRTHRHSMEIRTPDINPAWAYSRGIRPVGRFNH2) were used in the experiments. Palm-PrRP31 was 
synthesized and purified at the Institute of Organic Chemistry and Biochemistry, Prague, Czech Republic, as described previously (Maletínská et al. 2015, Popelová et al. 2018). JMV236 and palm-PrRP31 were dissolved in saline (Sal), while Dev was dissolved in Sal containing $15 \%$ DMSO.

\section{Experimental design}

Male C57BL/6J mice from Charles River Laboratories (Sulzfeld, Germany) were housed at a temperature of $23{ }^{\circ} \mathrm{C}$ and a relative humidity of $45-65 \%$ with a daily $12 \mathrm{~h}$ light/dark cycle (lights on at 6:00 am). The mice were given ad libitum water and a standard rodent chow diet Ssniff R/M-H (Ssniff Spezialdiäten GmbH, Soest, Germany) and were housed at five mice per cage until three months of age. All animal experiments followed the ethical guidelines for animal experiments of the European Union Directive (2010/63/EU) and the Act of the Czech Republic Nr. 246/1992 and were approved by the Committee for experiments with Laboratory Animals of the Academy of Sciences of the Czech Republic.

In both experiments, individually housed overnight-fasted $(16 \mathrm{~h}$ ) mice (body weight $27.2 \mathrm{~g} \pm$ $0.27 \mathrm{~g}$ ) provided ad libitum to water were used. In both experiments, fasted mice were randomly divided into eight experimental groups: 1) Sal/Sal, 2) Sal/palmPrRP31， 3) JMV236/Sal, 4) JMV236/palm-PrRP31, 5) Dev/Sal, 6) Dev/palm-PrRP31, 7) Dev/JMV236 and 8) Dev/JMV236 and palm-PrRP31. The first intraperitoneal (i.p., $0.15 \mathrm{ml}$ ) administration of Sal, Dev $(1 \mathrm{mg} / \mathrm{kg})$ and JMV236 $(7 \mu \mathrm{g} / \mathrm{kg})$ was thirty minutes later followed by a second subcutaneous (s.c., $0.15 \mathrm{ml}$ ) treatment with Sal and palm-PrRP31 $(1 \mathrm{mg} / \mathrm{kg})$ or i.p. treatment by JMV236 $(7 \mu \mathrm{g} / \mathrm{kg})$. The applied doses of JMV236, Dev and palm-PrRP31 were selected according to previously published data (Maletínská et al. 1992, Maletínská et al. 2008, Maletínská et al. 2015).

\section{Food intake study}

Rodent chow pellets were given to fasted mice ( $\mathrm{n}=6$ per group) $30 \mathrm{~min}$ after the second injection. The pellets were weighed every $30 \mathrm{~min}$ (noncumulative food intake) for the next 5 hours. The cumulative food intake was calculated by progressive summation of noncumulative food intakes during the individual time intervals. In all animals, the residual effect of the applied drugs was excluded based on nonsignificant differences in the amount of food intake during the first $24 \mathrm{~h}$ after drug administration compared to Sal/Sal treatment. For ethical reasons and for the validity, reproducibility, and respectability of the obtained data, the food intake study was repeated after 7 days in the same mice, and all data were pooled.

\section{Immunohistochemical study}

Fasted mice ( $\mathrm{n}=5$ per group) were deeply anesthetized with sodium pentobarbital $(50 \mathrm{mg} / \mathrm{kg}$, i.p.) ninety minutes after the second injection. The mice were transcardially perfused with ice-cold saline with heparin (10 U/ml, Zentiva, Prague, Czech Republic), and the brains were removed and postfixed in $0.1 \mathrm{M}$ phosphate buffer (PB, pH 7.4) containing $4 \%$ paraformaldehyde. To prevent diurnal variations in c-Fos expression, this part of the experiment was performed between 7:00 and 12:00 a.m.

\section{Immunohistochemical staining}

After $24 \mathrm{~h}$ of fixation, the brains were stored in a $20 \%$ sucrose solution in PB with $0.1 \%$ sodium azide at $4{ }^{\circ} \mathrm{C}$ and cut into $30 \mu \mathrm{m}$ coronal sections using a cryostat (CM1950; Leica Biosystems, Germany). c-Fos immunohistochemistry was performed with rabbit c-Fos monoclonal antibody (1:2000; \#2250S; Cell Signaling Technology, Inc., Danvers, MA, USA) according to the protocol described earlier (Pirnik et al. 2018). Consecutive PrRP immunostaining with rabbit polyclonal PrRP-31 antibody (1:500; \#H-008-52; Phoenix Pharmaceuticals, Inc., Burlingame, CA, USA) was performed according to the same procedure as described above. The final PrRP immunoreactions were visualized by a single $\quad 0.01 \% \quad 3,3^{\prime}$-diaminobenzidine tetrahydrochloride (DAB; Millipore Sigma, Burlington, MA, USA) solution in $0.05 \mathrm{M}$ Tris buffer ( $\mathrm{pH} \mathrm{7.4)} \mathrm{and}$ $0.0006 \% \mathrm{H}_{2} \mathrm{O}_{2}$. The development time $(6 \mathrm{~min})$ of the DAB immunostaining was monitored under a light microscope to reach the appropriate yellow-brownish color. Finally, the sections were mounted into $0.5 \%$ gelatin dissolved in $0.05 \mathrm{M}$ sodium acetate buffer (pH 6.0), air-dried and cover-slipped with Permount (Millipore Sigma, Burlington, MA, USA). The immunostaining of the negative control, which did not show any antiserum immunolabeling, included the substitution of the primary antisera with normal rabbit serum and the sequential elimination of the primary and secondary antibodies from the staining series.

The c-Fos immunoreactive cells were counted separately on each side of the appropriate coronal brain 
sections ( $\mathrm{n}=3-4$ sections/mouse) within the PVN (from bregma $-0.7 \mathrm{~mm}$ to $-0.94 \mathrm{~mm}$ ) according to the mouse brain atlas (Paxinos 2004). In the same way, PrRP-, FosPrRP- and Fos-immunopositive cells were counted within the caudal NTS (from bregma -7.48 to $-7.76 \mathrm{~mm}$ ) according to the same mouse brain atlas based on (Ganchrow et al. 2014). Quantitative assessment of the immunostained cells was performed manually in CellCounter1.2. from digital images of the selected areas captured with an Olympus AX70 light microscope and digital camera (Olympus DP70; Olympus Europa SE \& Co. KG, Hamburg, Germany). Images of representative sections were captured by the same microscope and digital camera.

\section{Statistical analysis}

All obtained data were first checked for normal distribution by the Shapiro-Wilks test in Statistica 7.0 (StatSoft) and SigmStat 4.0 (Systat). Square root normalized data from Fos immunoreactive cell counts in the PVN were analyzed by two-way ANOVA followed by Tukey's post hoc comparison (SigmStat 4.0, Systat). If the distribution of the data was also nonnormal after square root data normalization (data obtained from noncumulative and cumulative food intake, data obtained from the immunohistochemical studies related to cNTS), then nonparametric Kruskal-Wallis analysis followed by Student-Newman-Keuls multiple comparison was performed. All the results are reported as the mean \pm
SEM. Differences were considered significant at $\mathrm{p}<0.05$.

\section{Results}

Food intake and Fos neuronal activation in fasted mice did not differ between mice treated with Sal and the CCK1 receptor antagonist Dev alone.

In overnight-fasted Sal mice, the maximal food intake was observed during the first half-hour interval (Fig. 1). The second maximal peak of noncumulative food intake during the second half-hour interval did not exceed $40 \%$ of its noncumulative food intake in the first time interval (Fig. 1). Dev alone did not significantly influence the normal pattern of food consumption in overnight-fasted mice compared to the Sal group (Fig. 1, Fig. 2).

In the caudal NTS (cNTS), almost no c-Fosimmunopositive cells (Fig. 3A, C) or c-Fosimmunopositive PrRP neurons (Fig. 3B, C) were detected in the Sal or Dev alone group. In the PVN, only a minimal number of c-Fos-immunopositive cells was found after Sal or Dev administration alone (Fig. 4A,B). Moreover, the number of Fos-immunoreactive cells in the PVN did not significantly differ between Sal and Dev alone (Fig. 4A,B).

Onset of the anorexigenic effect of the CCK analog JMV236 is accompanied by Fos activation of PrRP neurons of the cNTS via CCK1 receptors.
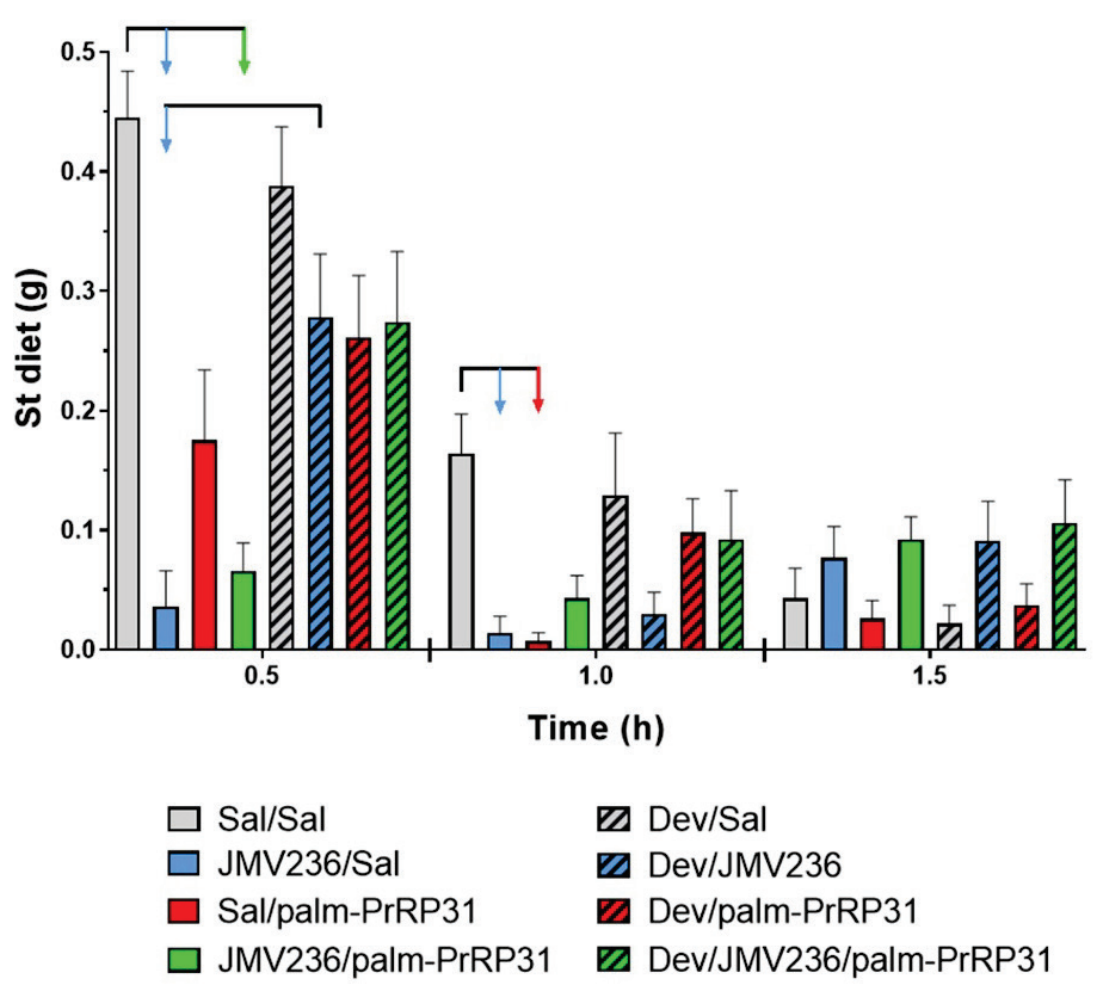

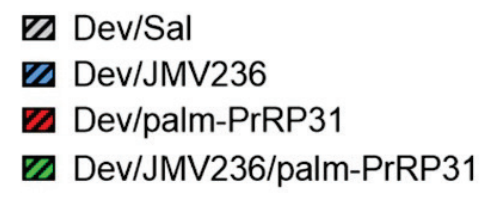

Fig. 1. Non-cumulative food intake of fasted mice ( $n=12$ per group) treated by Sal or Dev $(1 \mathrm{mg} / \mathrm{kg})$ and followed by Sal, JMV236 $(7 \mu \mathrm{g} / \mathrm{kg})$, palm-PrRP31 $(1 \mathrm{mg} / \mathrm{kg})$ and JMV236 (7 $\mu \mathrm{mg} / \mathrm{kg}) /$ palm-PrRP31 $(1 \mathrm{mg} / \mathrm{kg})$. Dev pretreatment of mice suppressed anorexigenic effect of JMV236 and was able to partially block anorexigenic effect of palm-PrRP31 and JMV236/palmPrRP31 in time interval which covered time interval of immunohistochemical study. $p<0.05$ for each group represented by arrow [nonparametric Kruskal-Wallis analysis, $\mathrm{H}(7, \mathrm{~N}=96)=42.728, \mathrm{p}<0.0001]$, Sal - saline, Dev - devazepide, palmPrRP31 - palmitoylated prolactin-releasing peptide 31 

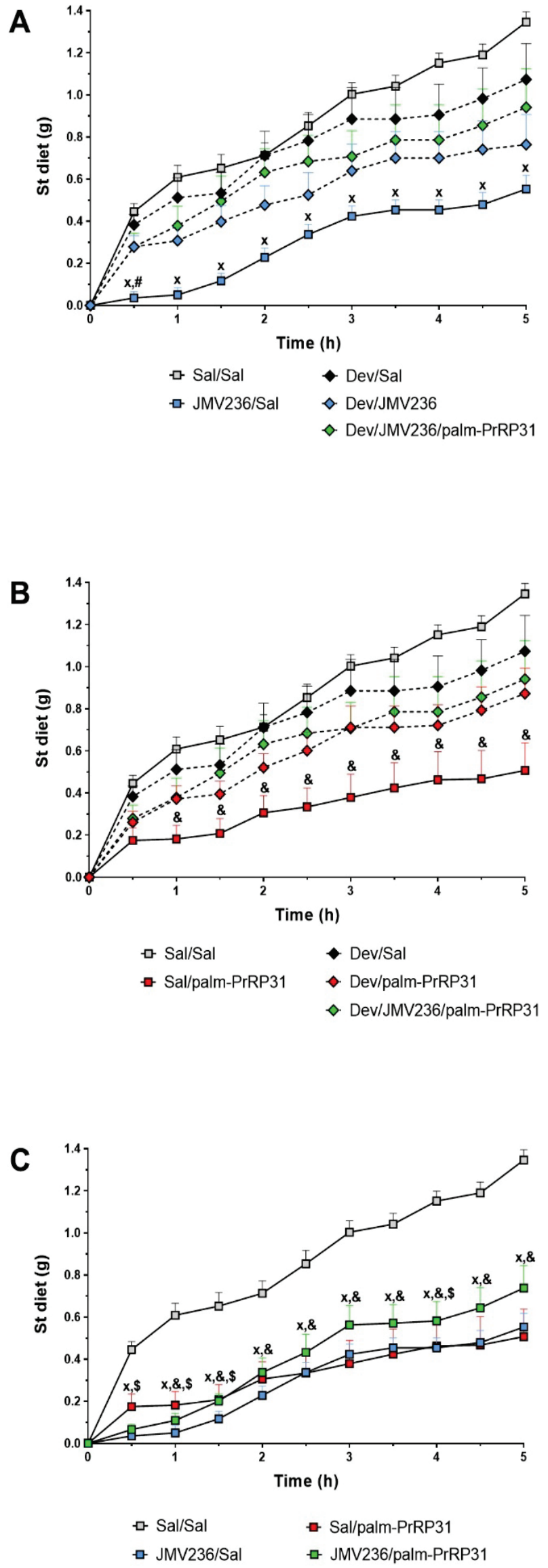

Fig. 2. Cumulative food intake of fasted mice ( $n=12$ per group) treated by Sal or Dev $(1 \mathrm{mg} / \mathrm{kg})$ and followed by Sal, JMV236 $(7 \mu \mathrm{g} / \mathrm{kg})$, palm-PrRP31 $(1 \mathrm{mg} / \mathrm{kg})$ and JMV236 $(7 \mu \mathrm{g} / \mathrm{kg}) / \mathrm{palm}-$ PrRP31 (1 mg/kg). (A) Dev pretreatment of mice suppressed anorexigenic effect of JMV236, (B) In Dev pretreated group of mice no significant differences between Dev alone and Dev/palmPrRP31 was achieved on food intake, (C) The anorexigenic effect of palm-PrRP31 after JMV236 treatment. Please note that in Dev pretreated group of mice no significant anorexigenic effect of JMV236/palm-PrRP31 was achieved as in Dev alone. ${ }^{x} p<0.05$ for JMV236/Sal vs Sal/Sal, " $p<0.05$ for JMV236/Sal vs Dev/JMV236, ${ }^{\&} p<0.05$ for Sal/palm-PrRP31 vs Sal/Sal and ${ }_{p}<0.05$ for JMV236/palm-PrRP31 vs Sal/Sal [nonparametric Kruskal-Wallis analysis, $\mathrm{H}(7, \mathrm{~N}=96)=42.728, \mathrm{p}<0.0001]$, Sal - saline, Dev devazepide, palm-PrRP31 - palmitoylated prolactin-releasing peptide 31

Peripheral administration of JMV236 to overnightfasted mice significantly lowered noncumulative food intake during the first and second half-hour intervals by almost $92 \%$ compared to Sal alone (Fig. 1, p<0.05). This anorexigenic effect of JMV236 was significantly attenuated by Dev pretreatment (Fig. 1, $\mathrm{p}<0.05$ ). In overnight-fasted mice, compared to Sal alone, a significant anorexigenic effect of JMV236 on cumulative food intake during all the measured time intervals was observed (Fig. 2A, $\mathrm{p}<0.05$ ). No significant differences between Dev/JMV236 and Dev alone were found in noncumulative or cumulative food intake (Fig. 1, Fig. 2A).

The onset of the JMV236 effect on food intake was accompanied by a significantly increased number of Fos-immunopositive cells in the cNTS (Fig. 3A,C, $\mathrm{p}<0.05$ ) and PVN compared to Sal alone (Fig. 4A,B, $\mathrm{p}<0.05)$. At the same time, approximately one-third of PrRP neurons in the cNTS were significantly activated after JMV236 administration compared to Sal alone (Fig. 3B,C, p<0.05). JMV236-induced c-Fos expression in PrRP cNTS neurons and PVN cells was almost completely suppressed by Dev pretreatment (Fig. 3B, C, $\mathrm{p}<0.05$, Fig. 4A, B, $\mathrm{p}<0.05$ ).

Pretreatment with Dev partially blocked the anorexigenic effect of palm-PrRP31

During the first and second half-hour intervals, palm-PrRP31 reduced noncumulative food intake by almost $61 \%$ (Fig. 1, p=0.055) and $96 \%$, respectively (Fig. 1, $\mathrm{p}<0.05$ ), compared to Sal alone. Except for the first half-hour (Fig. 2B, p=0.055), palm-PrRP31 also had a significant suppressive effect on cumulative food intake compared to Sal alone (Fig. 2B, p<0.05). On the other hand, no significant differences between Dev/palmPrRP31 and Dev alone on food intake were achieved (Fig. 1, Fig. 2B). 
A

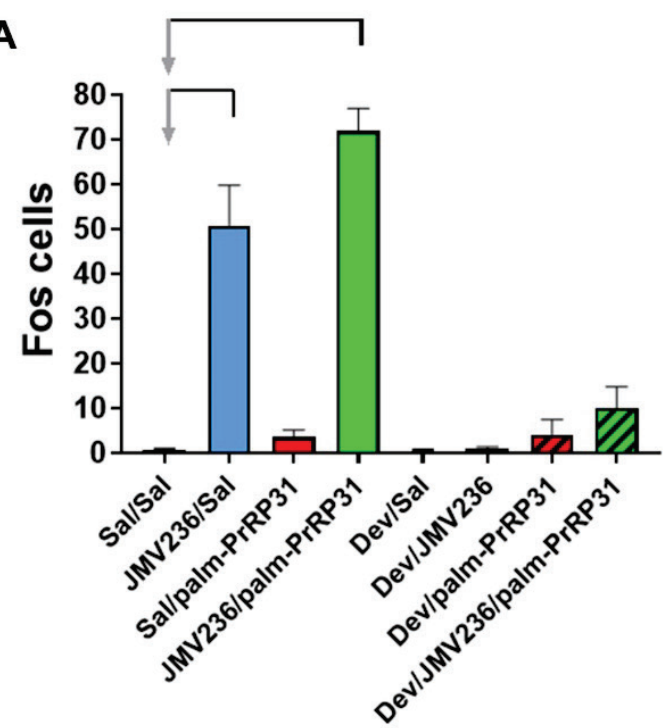

C
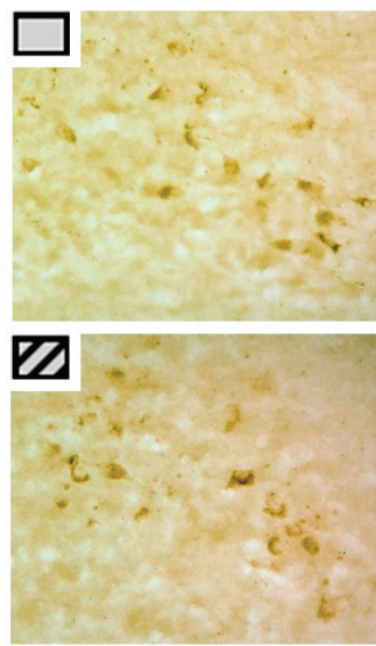
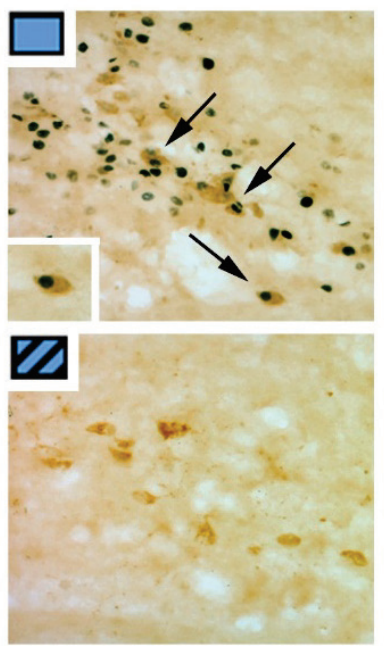

B

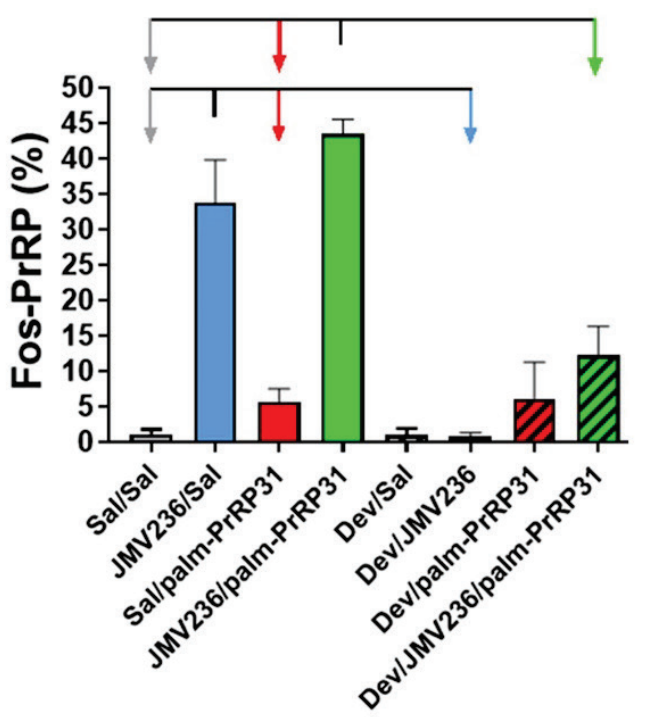

Fig. 3. cNTS: Fos cell immunoreactivity in brainstem cNTS 90 min after last injection in mice ( $n=5$ per group) treated by Sal or Dev $(1 \mathrm{mg} / \mathrm{kg})$ and followed Sal, JMV236 $(7 \mu \mathrm{g} / \mathrm{kg})$, palm-PrRP31 $(1 \mathrm{mg} / \mathrm{kg})$ and JMV236 $(7 \mu \mathrm{g} / \mathrm{kg}) / \mathrm{palm}-\operatorname{PrRP3} 1(1 \mathrm{mg} / \mathrm{kg})$. (A) In Sal pretreated group of mice JMV236 and JMV236/palm-PrRP31 significantly increased the number of Fos immunopositive cells, (B) Dev pretreatment significantly reduced percentage of Fos-PrRP immunostained neurons in mice treated JMV236 and JMV236/palm-PrRP31, (C) Representative photographs of Fos immunostained cells and Fos-PrRP immunostained neurons (black arrows) with detail photograph of one colocalization. $\mathrm{p}<0.05$ for each group represented by arrow [Fos: nonparametric Kruskal-Wallis analysis, $H(7, N=5)=28.356, p<0.001$, percentage of Fos-PrRP: nonparametric Kruskal-Wallis analysis, $H(7, N=5)=31.388$, $p<0.001]$, Sal - saline, Dev - devazepide, palm-PrRP31 - palmitoylated prolactin-releasing peptide 31, cNTS - caudal nucleus of the solitary tract

The onset of the anorexigenic effect of palmPrRP31 was not accompanied by a significantly changed number of c-Fos-immunopositive cells in either the cNTS (Fig. 3A,C) or PVN (Fig. 4A,B) or Fos-PrRP neurons in the cNTS (Fig. 3B,C) compared to Sal alone. Dev in combination with palm-PrRP31 did not affect the number of Fos- or Fos-PrRP-immunopositive cells in the cNTS compared to Dev alone (Fig. 4A,B,C). In the PVN, Dev/palm-PrRP31-treated animals exhibited a significantly increased number of Fos immunopositive cells compared to Dev alone (Fig. 4A,B, $\mathrm{p}<0.05$ ).
Anorexigenic effect of palm-PrRP31 in fasted mice was not affected by the CCK analog JMV236, but pretreatment with Dev partially blocked the anorexigenic effect of JMV236-palm-PrRP31

In the Sal pretreatment group, the anorexigenic effects achieved by JMV236, palm-PrRP31 and JMV236/palm-PrRP31 did not differ significantly from each other at any time (Fig. 2C). The onset of the anorexigenic activity of JMV236/palm-PrRP31 was achieved at the same time as JMV236 and earlier than the onset of the anorexigenic activity of palm-PrRP31 (Fig. 1). 
A

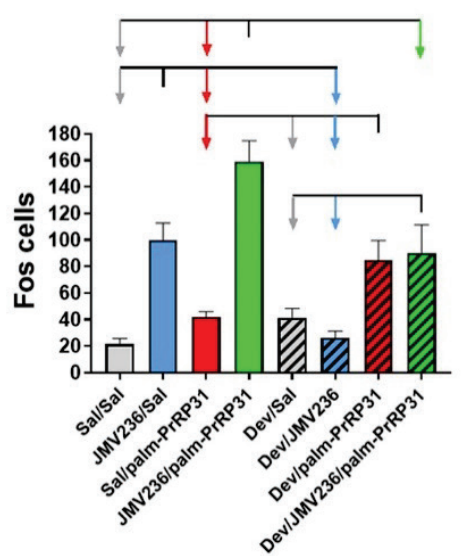

B

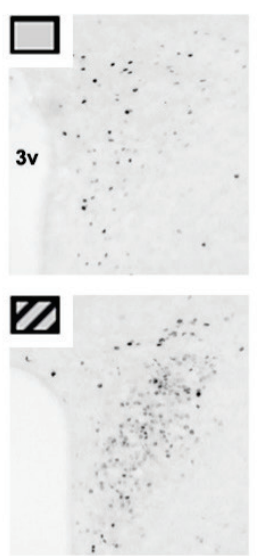

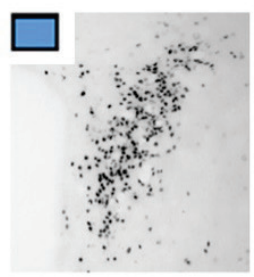

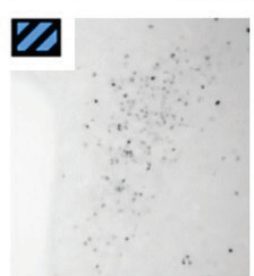

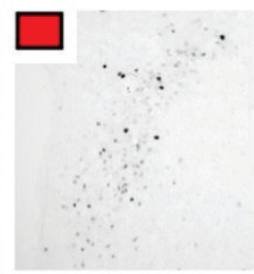
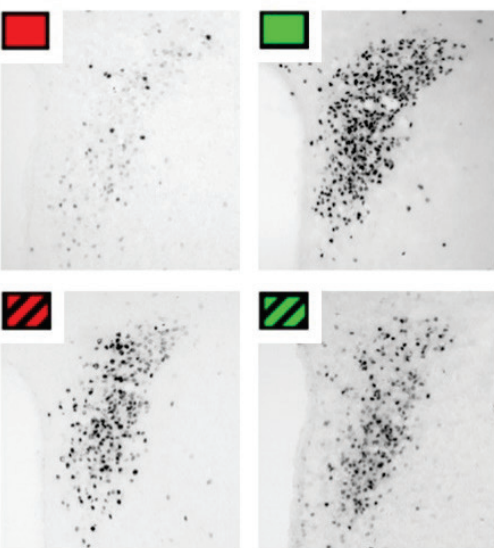

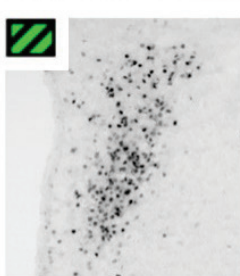

Fig. 4. $P V N$ : Fos cell immunoreactivity in PVN $90 \mathrm{~min}$ after last injection in mice ( $\mathrm{n}=5$ per group) treated by Sal or Dev (1 mg/kg) and followed Sal, JMV236 (7 $\mu \mathrm{g} / \mathrm{kg})$, palm-PrRP31 $(1 \mathrm{mg} / \mathrm{kg})$ and JMV236 $(7 \mu \mathrm{gg} / \mathrm{kg}) / \mathrm{palm}$-PrRP31 $(1 \mathrm{mg} / \mathrm{kg})$. (A) Dev pretreatment significantly reduced number of Fos immunopositive cells in mice treated JMV236 and JMV236/palm-PrRP31 but significantly increased number of Fos immunopositive cells in mice treated palm-PrRP31, (B) Representative photographs of Fos immunostained cells. $p<0.05$ for each group represented by arrow [two-way ANOVA, treatment: $F(1,3)=20.438, p<0.001$, pretreatment $x$ treatment: $F(1,3)=13.93$, $\mathrm{p}<0.001]$, Sal - saline, Dev - devazepide, palm-PrRP31 - palmitoylated prolactin-releasing peptide 31, PVN - paraventricular hypothalamic nucleus, $3 \mathrm{v}$ - third brain ventricle

No significant differences between Dev alone and Dev combined with JMV236/palm-PrRP31, JMV236 and palm-PrRP31 in effect on food intake were found (Fig. 1, Fig. 2).

In the Sal-pretreated groups, the onset of the anorexigenic effect of JMV236/palm-PrRP31 and JMV236 was associated with a significantly increased number of Fos-immunolabeled PrRP neurons in the cNTS compared to palm-PrRP31 (Fig. 3B,C, p<0.05). A similar effect was detected in the PVN: JMV236/palmPrRP31 and JMV236 exhibited significantly more activated cells than palm-PrRP31 (Fig. 4A, B, p<0.05). No significant differences in the number of Fosimmunolabeled cells in either the cNTS or PVN or in the number of Fos-immunolabeled PrRP neurons in the cNTS were found between the JMV236/palm-PrRP31 and JMV236 groups (Fig. 3A,B,C, Fig. 4A,B).

Dev in combination with JMV236/palm-PrRP31 significantly reduced the number of Fos-immunolabeled PrRP neurons in the cNTS (Fig. 3B, C, p <0.05) and the number of Fos-immunolabeled cells in the PVN compared to those of the JMV236/palm-PrRP31 group (Fig. 4A,B, $\mathrm{p}<0.05$ ). In addition, a significant parallel decrease in the number of Fos-PrRP neurons in the cNTS and Fos-immunolabeled cells in the PVN also occurred in the Dev/JMV236 group compared to the JMV236 alone group (Fig. 3B,C, $<<0.05$, Fig. $4 A, B, p<0.05$ ). On the other hand, Dev pretreatment with palm-PrRP31 significantly increased the number of Fos-immunolabeled cells in the PVN compared to palm-PrRP31 alone (Fig. $4 \mathrm{~A}, \mathrm{~B}, \mathrm{p}<0.05)$.

In the Dev-pretreated groups, JMV236, palmPrRP31 or JMV236/palm-PrRP31 did not affect the number of Fos- or Fos-PrRP neurons in the cNTS compared to Dev alone (Fig. 3). On the other hand, the number of Fos immunolabeled cells in the PVN of Dev/JMV236/palm-PrRP31 was comparable to that of Dev/palm-PrRP31 group and was significantly higher than in the Dev/JMV236 and Dev alone (Fig. 4A,B, $\mathrm{p}<0.05)$.

\section{Discussion}

The present study aimed to elucidate the anorexigenic effect of peripherally applied palmitoylated prolactin-releasing peptide in the context of pharmacological manipulation of the "silent" cholecystokinin system in fasted mice.

Our data showed that the 1) onset of the anorexigenic effect of peripherally applied CCK agonist JMV236 was accompanied by significant Fos activation of PrRP neuronal population of the caudal NTS and by significant Fos cell activation in the PVN; 2) peripheral palm-PrRP31 administration in low anorexigenic dose was not associated with significant Fos activation of PrRP neuronal population in cNTS or Fos cell activation in PVN; 3) pretreatment with Dev was able to partially block anorexigenic effect of palm-PrRP31 and increase 
Fos cell activation in PVN; and 4) although combination of peripherally administered JMV236 and palm-PrRP31 did not show additive anorexigenic effect in fasted mice, it caused enhancement of Fos neuronal activity both in NTS and PVN which was partially suppressed by Dev pretreatment.

In our study, Fos cell activation in the NTS and PVN was studied after peripheral administration of the CCK analogs JMV236 and palm-PrRP31 for several reasons. First, among the key brainstem and hypothalamic structures that are involved in homeostatic food intake regulation, only the NTS and PVN were found to be significantly activated after acute peripheral CCK administration (Lawrence et al. 2002, Maletínská et al. 2008, Pirnik et al. 2010). Second, the NTS and the hypothalamic DMN are the main locations of brain PrRP neurons (Maruyama et al. 1999, Morales et al. 2000, Roland et al. 1999); however, only PrRP neurons in the NTS were shown to be involved in mediating the central satiety effect of CCK (Bechtold and Luckman 2006, Lawrence et al. 2002) while PrRP neurons in the DMN seem to be regulated by energy status (Lawrence et al. 2000). Third, prominent PrRP fiber innervation from the NTS to the PVN was described (Morales et al. 2000), and the CCK-PrRP-oxytocin PVN pathway was identified as critical for controlling meal size (Yamashita et al. 2013). In addition, although the PVN contains a lower number of GPR10 receptors than the DMN and NTS (Roland et al. 1999), our data with another palmitoylated PrRP analog indicated that while DMN cells might be associated with the process of long-term adaptation to modified energy homeostasis, activated PVN and NTS cells are instead also associated with the anorexigenic effect of lipidized analogs of PrRP (Pirník et al. 2018).

Our data showed that the anorexigenic effect of JMV236, which was accompanied by cell activation in the NTS and PVN, was inhibited by the selective CCK1 receptor antagonist Dev. Dev is able to cross the bloodbrain barrier (BBB) (Woltman et al. 1999) and thus could be able to inhibit the anorexigenic effect of JMV236 via central CCK1 receptors. On the other hand, peripheral CCK1 receptors are involved in the central anorexigenic effect of CCK (Reidelberger et al. 2003), and JMV236 is analogously a CCK peptide agonist, as endogenous CCK is unable to cross the BBB (Passaro et al. 1982), and its central anorexigenic effect is probably indirect. The anorexigenic effect of JMV236 lasted several hours after its i.p. administration (Gourch et al. 1990, Maletínská et al. 1992). Moreover, JMV236 can inhibit food intake in rats only after its peripheral i.p. but not central i.c.v. administration (Gourch et al. 1990). Our study indicates that significant activation of PVN cells after peripheral JMV236 administration may be a consequence of the activation of peripheral CCK1 receptors and is probably associated with PrRP neurons of the NTS. On the other hand, the activation of cocaine- and amphetamineregulated transcript (CART)-positive neurons in the PVN was also associated with the activation of NTS cells after peripheral CCK administration (Peter et al. 2010). In addition, a significant synergistic anorexigenic effect of peripheral CCK and central CART peptide in mice was also described (Maletínská et al. 2008). From this point of view, another neuronal system may also participate in the central anorexigenic effect observed after peripheral JMV236 administration.

In addition, the onset of the anorexigenic effect of JMV236/palm-PrRP31 and JMV236 was associated with a significantly increased number of Fosimmunolabeled PrRP neurons in the cNTS compared to that of palm-PrRP31. In addition, peripheral palmPrRP31 administration at a dose of $1 \mathrm{mg} / \mathrm{kg}$ was associated only with nonsignificant PVN cell activation in our study. Recently, we showed that the central anorexigenic effect of peripherally administered palmPrRP31 (5 mg/kg, s.c.) in mice was accompanied by significant Fos cell activation of the brainstem cNTS as well as hypothalamic PVN-Arc-DMN activation (Pirnik et al. 2015). In addition, a significant number of oxytocin PVN neurons and hypocretin LHA neurons were also activated after s.c. administration of palm-PrRP31 at dose of $5 \mathrm{mg} / \mathrm{kg}$ (Pirnik et al. 2015). In our study, only a nonsignificant increase in Fos cell activity in the cNTS and PVN after a lower palm-PrRP31 dose (1 mg/kg, s.c.), despite its significant anorexigenic effect, could be explained by a delayed onset of its anorexigenic activity that was already published for both doses (Maletínská et al. 2015).

This study showed that Dev alone did not significantly influence food intake and cell activation in the cNTS and PVN in overnight-fasted mice compared to Sal, but Dev pretreatment was able to significantly diminish food intake and Fos activation in both the NTS and PVN after JMV236 administration. Dev pretreatment was also able to partially reduce palm-PrRP-mediated food intake inhibition and to decrease Fos activation in response to combined JMV236 and palm-PrRP treatment in both the NTS and PVN. Moreover, our data also showed that peripheral Dev administration in fasted 
animals increased the number of Fos immunopositive cells in the PVN after palm-PrRP administration at a dose of $1 \mathrm{mg} / \mathrm{kg}$. It must be mentioned that the plasma level of endogenous CCK in fasted animals is low (Playford et al. 1993), and in our study, Dev did not affect food intake when administered to overnight-fasted animals. In addition, even though Dev was able to increase CCK synthesis in the gastrointestinal tract of fasted animals, it was not able to increase plasma CCK levels (Playford et al. 1993). Although our data indicated that Dev could act peripherally to antagonize the action of JMV236, due to the low endogenous peripheral plasma CCK levels in fasted animals, the central effect of Dev should probably be considered. As shown previously, Dev can bind to CCK1 receptors located in the vagus nerve as well as in NTS neurons (Corp et al. 1993) and is able to cross the BBB (Woltman et al. 1999). On the other hand, food deprivation selectively increases the number of CCK1 receptors in the hypothalamus (Saito et al. 1981), and endogenous CCK is physiologically involved in feeding control during fasting via the hypothalamic PVN (Cano et al. 2003). As previously reported, CCK1 receptors are abundant in the PVN (Woodruff et al. 1991), and activation of CCK neurons of the NTS that innervate the PVN stimulates appetite (D'Agostino et al. 2016, Roman et al. 2017). In addition, i.p. administration of Dev did not alter food intake, although central i.c.v. administration of Dev increased food intake in fasted animals (Ebenezer 2002). Finally, i.p. Dev administration also resulted in almost complete loss of the anorexigenic effect of i.c.v. administered the CART peptide, whose anorexigenic effect was associated with PVN cell activation (Maletínská et al. 2008).

Thus, our data may indicate that the pharmacologically influenced CCK system may be involved in the central anorexigenic effect of peripherally applied palm-PrRP31. According to the Dev pretreatment, it cannot be excluded that both peripheral (mediated via brainstem NTS) and central mechanisms (mediated via hypothalamic PVN) may be involved in this effect. The central mechanism of the interaction between CCK and the PrRP neuronal system should be elucidated in future studies.

\section{Abbreviations}

AP, Area postrema; Arc, Arcuate hypothalamic nucleus; BBB, Blood-brain barrier; CART, Cocaine- and amphetamine-regulated transcript; $\mathrm{CCK}$, Cholecystokinin; cNTS, Caudal nucleus of the solitary tract; DAB, 3,3'-diaminobenzidine tetrahydrochloride; Dev, Devazepide; DMN, Dorsomedial hypothalamic nucleus; GIT, Gastrointestinal tract; i.c.v., Intracerebroventricular; i.p., Intraperitoneal; LHA, Lateral hypothalamic area; myr, myristoylated; palm, palmytoylated; PB, Phosphate buffer; PrRP, Prolactinreleasing peptide; PVN, Paraventricular hypothalamic nucleus; Sal, Saline; s.c, Subcutaneous

\section{Conflict of Interest}

There is no conflict of interest.

\section{Acknowledgements}

We would like to thank Hedvika Vysušilová for excellent assistance in food intake experiments and Miroslava Blechová for synthesis of palm-PrRP31. This work was supported by the Grant Agency of the Czech Republic GACR 18-10591S, RVO:67985823 and RVO:61388963 of Academy of Sciences of the Czech Republic.

\section{References}

BECHTOLD DA, LUCKMAN SM: Prolactin-releasing Peptide mediates cholecystokinin-induced satiety in mice. Endocrinology 147: 4723-4729, 2006. https://doi.org/10.1210/en.2006-0753

CANO V, EZQUERRA L, RAMOS MP, RUIZ-GAYO M: Characterization of the role of endogenous cholecystokinin on the activity of the paraventricular nucleus of the hypothalamus in rats. Br J Pharmacol 140: 964-970, 2003. https://doi.org/10.1038/sj.bjp.0705513

CORP ES, MCQUADE J, MORAN TH, SMITH GP: Characterization of type A and type B CCK receptor binding sites in rat vagus nerve. Brain Res 623: 161-166, 1993. https://doi.org/10.1016/0006-8993(93)90024-h

D'AGOSTINO G, LYONS DJ, CRISTIANO C, BURKE LK, MADARA JC, CAMPBELL JN, GARCIA AP, LAND BB, LOWELL BB, DILEONE RJ, HEISLER LK: Appetite controlled by a cholecystokinin nucleus of the solitary tract to hypothalamus neurocircuit. Elife 5, 2016. https://doi.org/10.7554/eLife.12225 
DODD GT, LUCKMAN SM: Physiological roles of GPR10 and PrRP signaling. Front Endocrinol (Lausanne) 4: 20, 2013. https://doi.org/10.3389/fendo.2013.00020

DODD GARRON T, WORTH AMY A, NUNN N, KORPAL AARON K, BECHTOLD DAVID A, ALLISON MARGARET B, MYERS MARTIN G, STATNICK MICHAEL A, LUCKMAN SIMON M: The thermogenic effect of leptin is dependent on a distinct population of prolactin-releasing peptide neurons in the dorsomedial hypothalamus. Cell Metabol 20: 639-649, 2014. https://doi.org/10.1016/j.cmet.2014.07.022

EBENEZER IS: Effects of intracerebroventricular administration of the CCK1 receptor antagonist devazepide on food intake in rats. Eur J Pharmacol 441: 79-82, 2002. https://doi.org/10.1016/S0014-2999(02)01485-1

ELLACOTT KLJ, LAWRENCE CB, ROTHWELL NJ, LUCKMAN SM: PRL-releasing peptide interacts with leptin to reduce food intake and body weight. Endocrinology 143: 368-374, 2002. https://doi.org/10.1210/endo.143.2.8608

GANCHROW D, GANCHROW JR, CICCHINI V, BARTEL DL, KAUFMAN D, GIRARD D, WHITEHEAD MC: Nucleus of the solitary tract in the C57BL/6J mouse: Subnuclear parcellation, chorda tympani nerve projections, and brainstem connections. J Comp Neurol 522: 1565-1596, 2014. https://doi.org/10.1002/cne.23484

GOURCH A, OROSCO M, RODRIGUEZ M, MARTINEZ J, COHEN Y, JACQUOT C: Effects of a new cholecystokinin analogue (JMV 236) on food intake and brain monoamines in the rat. Neuropeptides 15: 37-41, 1990. https://doi.org/10.1016/0143-4179(90)90158-u

IBATA Y, IIJIMA N, KATAOKA Y, KAKIHARA K, TANAKA M, HOSOYA M, HINUMA S: Morphological survey of prolactin-releasing peptide and its receptor with special reference to their functional roles in the brain. Neurosci Res 38: 223-230, 2000. https://doi.org/10.1016/s0168-0102(00)00182-6

KUNEŠ J, PRAŽIENKOVÁ V, POPELOVÁ A, MIKULÁŠKOVÁ B, ZEMENOVÁ J, MALETÍNSKÁ L: Prolactinreleasing peptide: a new tool for obesity treatment. J Endocrinol 230: R51-R58, 2016. https://doi.org/10.1530/joe-16-0046

LAWRENCE CB, CELSI F, BRENNAND J, LUCKMAN SM: Alternative role for prolactin-releasing peptide in the regulation of food intake. Nat Neurosci 3: 645-646, 2000. https://doi.org/10.1038/76597

LAWRENCE CB, ELLACOTT KL, LUCKMAN SM: PRL-releasing peptide reduces food intake and may mediate satiety signaling. Endocrinology 143: 360-367, 2002. https://doi.org/10.1210/endo.143.2.8609

LUCKMAN SM: Fos-like immunoreactivity in the brainstem of the rat following peripheral administration of cholecystokinin. J Neuroendocrinol 4: 149-152, 1992. https://doi.org/10.1111/j.1365-2826.1992.tb00152.x

MALETÍNSKÁ L, LIGNON M-F, GALAS M-C, BERNAD N, PÍRKOVÁ J, HLAVÁČEK J, SLANINOVÁ J, MARTINEZ J: Pharmacological characterization of new cholecystokinin analogues. European Journal of Pharmacology 222: 233-240, 1992. https://doi.org/10.1016/0014-2999(92)90861-W

MALETÍNSKÁ L, MAIXNEROVÁ J, MATYŠKOVÁ R, HAUGVICOVÁ R, PIRNÍK Z, KISS A, ŽELEZNÁ B: Synergistic effect of CART (cocaine- and amphetamine-regulated transcript) peptide and cholecystokinin on food intake regulation in lean mice. BMC Neuroscience 9: 101, 2008. https://doi.org/10.1186/1471-2202-9-101

MALETÍNSKÁ L, NAGELOVÁ V, TICHÁ A, ZEMENOVÁ J, PIRNÍK Z, HOLUBOVÁ M, ŠPOLCOVÁ A, MIKULÁŠKOVÁ B, BLECHOVÁ M, SÝKORA D, LACINOVÁ Z, HALUZÍK M, ŽELEZNÁ B, KUNEŠ J: Novel lipidized analogs of prolactin-releasing peptide have prolonged half-lives and exert anti-obesity effects after peripheral administration. Int J Obes (Lond) 39: 986-993, 2015. https://doi.org/10.1038/ijo.2015.28

MANISCALCO JW, RINAMAN L: Overnight food deprivation markedly attenuates hindbrain noradrenergic, glucagon-like peptide-1, and hypothalamic neural responses to exogenous cholecystokinin in male rats. Physiol Behav 121: 35-42, 2013. https://doi.org/10.1016/j.physbeh.2013.01.012

MARUYAMA M, MATSUMOTO H, FUJIWARA K, KITADA C, HINUMA S, ONDA H, FUJINO M, INOUE K: Immunocytochemical localization of prolactin-releasing peptide in the rat brain. Endocrinology 140: 2326-2333, 1999. https://doi.org/10.1210/endo.140.5.6685

MORALES T, HINUMA S, SAWCHENKO PE: Prolactin-releasing peptide is expressed in afferents to the endocrine hypothalamus, but not in neurosecretory neurones. J Neuroendocrinol 12: 131-140, 2000. https://doi.org/10.1046/j.1365-2826.2000.00428.x 
PASSARO E, JR., DEBAS H, OLDENDORF W, YAMADA T: Rapid appearance of intraventricularly administered neuropeptides in the peripheral circulation. Brain Res 241: 335-340, 1982.

PAXINOS GF, K.B.J.: The Mouse Brain in Stereotaxic Coordinates, USA: Academic Press. 2004.

PETER L, STENGEL A, NOETZEL S, INHOFF T, GOEBEL M, TACHÉ Y, VEH RW, BANNERT N, GRÖTZINGER C, WIEDENMANN B, KLAPP BF, MÖNNIKES H, KOBELT P: Peripherally injected CCK-8S activates CART positive neurons of the paraventricular nucleus in rats. Peptides 31: 1118-1123, 2010. https://doi.org/10.1016/j.peptides.2010.03.013

PETERS JH, SIMASKO SM, RITTER RC: Modulation of vagal afferent excitation and reduction of food intake by leptin and cholecystokinin. Physiol Behav 89: 477-485, 2006. https://doi.org/10.1016/j.physbeh.2006.06.017

PIRNIK Z, KOLESÁROVÁ M, ŽELEZNÁ B, MALETÍNSKÁ L: Repeated peripheral administration of lipidized prolactin-releasing peptide analog induces c-fos and FosB expression in neurons of dorsomedial hypothalamic nucleus in male C57 mice. Neurochem Int 116: 77-84, 2018. https://doi.org/10.1016/j.neuint.2018.03.013

PIRNIK Z, MAIXNEROVÁ J, MATYSKOVÁ R, KOUTOVÁ D, ZELEZNÁ B, MALETÍNSKÁ L, KISS A: Effect of anorexinergic peptides, cholecystokinin (CCK) and cocaine and amphetamine regulated transcript (CART) peptide, on the activity of neurons in hypothalamic structures of C57B1/6 mice involved in the food intake regulation. Peptides 31: 139-144, 2010. https://doi.org/10.1016/j.peptides.2009.09.035

PIRNIK Z, ŽELEZNÁ B, KISS A, MALETÍNSKÁ L: Peripheral administration of palmitoylated prolactin-releasing peptide induces Fos expression in hypothalamic neurons involved in energy homeostasis in NMRI male mice. Brain Res 1625: 151-158, 2015. https://doi.org/10.1016/j.brainres.2015.08.042

PLAYFORD RJ, KING AW, DEPREZ PH, DE-BELLEROCHE J, FREEMAN TC, CALAM J: Effects of diet and the cholecystokinin antagonist; devazepide (L364,718) on CCK mRNA, and tissue and plasma CCK concentrations. Eur J Clin Invest 23: 641-647, 1993. https://doi.org/10.1111/j.1365-2362.1993.tb00725.x

POPELOVÁ, A KÁKONOVÁ A, HRUBÁ L, KUNEŠ J, MALETÍNSKÁ L, ŽELEZNÁ B: Potential neuroprotective and anti-apoptotic properties of a long-lasting stable analog of ghrelin: an in vitro study using SH-SY5Y cells. Physiol Res 67: 339-346, 2018. https://doi.org/10.33549/physiolres.933761

PRAŽIENKOVÁ V, HOLUBOVÁ M, PELANTOVÁ H, BUGÁŇOVÁ M, PIRNÍK Z, MIKULÁŠKOVÁ B, POPELOVÁ A, BLECHOVÁ M, HALUZÍK M, ŽELEZNÁ B, KUZMA M, KUNEŠ J, MALETÍNSKÁ L: Impact of novel palmitoylated prolactin-releasing peptide analogs on metabolic changes in mice with diet-induced obesity. PLoS One 12: e0183449-e0183449, 2017. https://doi.org/10.1371/journal.pone.0183449

PRAŽIENKOVÁ V, POPELOVÁ A, KUNEŠ J, MALETÍNSKÁ L: Prolactin-releasing peptide: physiological and pharmacological properties. Int J Mol Sci 20, 2019. https://doi.org/10.3390/ijms20215297

QUILLET R, AYACHI S, BIHEL F, ELHABAZI K, ILIEN B, SIMONIN F: RF-amide neuropeptides and their receptors in Mammals: Pharmacological properties, drug development and main physiological functions. Pharmacol Ther, 160: 84-132, 2016. https://doi.org/10.1016/j.pharmthera.2016.02.005

REIDELBERGER RD, CASTELLANOS DA, HULCE M: Effects of peripheral CCK receptor blockade on food intake in rats. Am J Physiol Regul Integr Comp Physiol 285: R429-437, 2003. https://doi.org/10.1152/ajpregu.00176.2003

ROLAND BL, SUTTON SW, WILSON SJ, LUO L, PYATI J, HUVAR R, ERLANDER MG, LOVENBERG TW: Anatomical distribution of prolactin-releasing peptide and its receptor suggests additional functions in the central nervous system and periphery. Endocrinology 140: 5736-5745, 1999. https://doi.org/10.1210/endo.140.12.7211

ROMAN CW, SLOAT SR, PALMITER RD: A tale of two circuits: CCK(NTS) neuron stimulation controls appetite and induces opposing motivational states by projections to distinct brain regions. Neuroscience 358: 316-324, 2017. https://doi.org/10.1016/j.neuroscience.2017.06.049

SAITO A, WILLIAMS JA, GOLDFINE ID: Alterations in brain cholecystokinin receptors after fasting. Nature 289: 599-600, 1981. https://doi.org/10.1038/289599a0

WALL KD, OLIVOS DR, RINAMAN L: High fat diet attenuates cholecystokinin-induced cFos activation of prolactinreleasing peptide-expressing a 2 noradrenergic neurons in the caudal nucleus of the solitary tract. Neuroscience 447: 113-121, 2020. https://doi.org/10.1016/j.neuroscience.2019.08.054 
WOLTMAN TA, HULCE M, REIDELBERGER RD: Relative blood-brain barrier permeabilities of the cholecystokinin receptor antagonists devazepide and A-65186 in rats. J Pharm Pharmacol 51: 917-920, 1999. https://doi.org/10.1211/0022357991773348

WOODRUFF GN, HILL DR, BODEN P, PINNOCK R, SINGH L, HUGHES J: Functional role of brain CCK receptors. Neuropeptides 19 Suppl: 45-56, 1991. https://doi.org/10.1016/0143-4179(91)90082-t

YAMASHITA M, TAKAYANAGI Y, YOSHIDA M, NISHIMORI K, KUSAMA M, ONAKA T: Involvement of prolactin-releasing peptide in the activation of oxytocin neurones in response to food intake. J Neuroendocrinol 25: 455-465, 2013. https://doi.org/10.1111/jne.12019 